\title{
Effect of Nitrogen Levels and Cutting Management on Nitrogen Content, Protein Content and Protein Yield of Fodder Oat (Avena sativa L.)
}

\author{
Bollaveni Sathish Kumar ${ }^{1 *}$, Raj Vir Singh ${ }^{1}$, Akhilesh Kumar Gupta ${ }^{1}$ and J. Ravinder ${ }^{2}$ \\ ${ }^{1}$ Department of agronomy, collage of agriculture, Sardar Vallabhbhai Patel University of \\ Agriculture and Technology, Meerut 250110 (U.P), India \\ ${ }^{2}$ Department of Soil Science and Agricultural Chemistry, Post Graduate Institute, Dr. Panjabrao \\ Deshmukh Krishi Vidyapeeth, Akola, Maharashtra, 444104, India \\ *Corresponding author
}

\section{A B S T R A C T}

The field experiment, conducted to evaluate the Effect of nitrogen levels and cutting management on growth, yield and quality of fodder oat (Avena sativa L.). A field experiment was conducted during Rabi season 2015-16 at Crop Research Centre (Chirauri) of Sardar Vallabhbhai Patel University of Agriculture and Technology, Meerut (U.P.) to evaluate the effect of nitrogen levels and cutting management on performance of fodder

\section{Keywords}

Yield,

Quality, Fodder,

Nitrogen levels.

Article Info

\section{Accepted:}

21 June 2017

Available Online:

10 July 2017 oat and chemical properties of soil. The area lie at a latitude of $29^{\circ} 40^{\prime}$ North and longitude of $77^{\circ} 42^{\prime}$ East with an elevation of 237 meters above mean sea level. The soil of the experimental field was well drained, sandy loam in texture and slightly alkaline in reaction. It was medium in available nitrogen and phosphorus but high in available potassium with an electrical conductivity (1:2, soil: water suspension) of $1.6 \mathrm{dS} / \mathrm{m}$. The treatments comprised 5 nitrogen levels $\left(0,40,80,120\right.$ and $\left.160 \mathrm{~kg} \mathrm{ha}^{-1}\right)$ and 2 cutting management (single at 50\% flowering and double at 60 DAS and 50\% flowering), replicated 4 times in a factorial randomized block design. The data on growth, physiology, green forage yield and quality and its contributing traits were calculated on net plot area basis $\left(16 \mathrm{~m}^{2}\right)$, whereas content and uptake in straw along with soil available nutrients and production economic, were recorded as per the standard procedure. The results indicated that nitrogen content, protein content and protein yield were significantly superior at 160 $\mathrm{kg}$ nitrogen $\mathrm{ha}^{-1}$. Likewise, double cut shows higher protein content than single cut management, single cut resulted into higher protein yield than their respective counterparts like double cutting (60DAS and $50 \%$ flowering). Nitrogen content in straw not influenced significantly by cutting management.

\section{Introduction}

Livestock population is the largest in India comprising 182.50 million cattle, among these, 61.30 million buffaloes, 76.65 million goats, 41.30 million sheep, 10.0 million pigs and 3.04 million other animals (Jatet al., 2014). India is having the largest livestock population, $15 \%$ of the world's livestock population (Neelar, 2011).
Livestock contributing 7\% to national GDP and source of employment and ultimate livelihood for $70 \%$ population in rural areas. Deficiency in feed and fodder has been identified as one of the major components in achieving the desired level of livestock production. At present, the country faces a net deficit of $63 \%$ green fodder, $24 \%$ dry crop 
residues and 64\% feeds (Kumar et al., 2012). The productivity of our livestock often remains low due to inadequate and nutritionally unbalanced supply of feed and fodder. Half of the total losses in livestock productivity are attributed to the inadequacy in supply of feed and fodder.

Deficiency of green fodder will be about $64.9 \%$ and for dry fodders up to $24.9 \%$ in 2025 A.D. Under such circumstances the only way to bridge the gap between demand and supply of the fodder is to ameliorate the forage resources. Among forages, oat (Avena sativa L.) is an important winter feed and forage crop. Owing to its excellent growth habit, better regeneration capacity and good quality forage, it is a promising forage crop. Oat being rich in carbohydrates, vitamins, minerals and total digestible nutrients, is widely used as supplement, hay and silage.

Oat (Avenasativa L.) is the important cereal (Gramineae) and forage crop, grown during rabi season and is next to berseem in nutritive value. It is also rich in energy, protein, vitamin $\mathrm{B}$, phosphorous and iron (Tiwana et al., 2008).It is cultivated in an area of 1021 million ha with an annual production of 233 million tons in the world (Anonymous, 2009). The total area covered under oat cultivation in India is about 1.0 million ha with $350-500 \mathrm{q}$ $\mathrm{ha}^{-1}$ green fodder productivity (IGFRI, 2011). In India, it is grown in Punjab, Haryana, Jammu \& Kashmir, Himachal Pradesh, Uttar Pradesh, Madhya Pradesh, Rajasthan, Maharashtra and West Bengal. The crop occupies maximum area in Uttar Pradesh (34\%) followed by Punjab (20\%), Bihar (16\%), Haryana (9\%) and Madhya Pradesh $(6 \%)$.

It is important winter crop in many parts of the world and is grown as multipurpose crop for grain, pasture, forage or as a rotation crop. Oat plant has excellent growth habit, quick recovery after cutting and good quality herbage. It is a palatable, succulent and nutritious crop. The protein quality of oat is excellent. Oat requires a long cool season for its growth; therefore, it is successfully grown in the northern plains and hilly areas of the country. Oat is mostly fed as green but surplus is converted into silage or hay to use during fodder deficit periods. Oat as a forage crop, has the advantage of being winter hardy and serves as catch crop.

There are several factors, which affect the productivity and quality of forage oat. Nitrogen is a one of the major component to influence the forage growth, yield and quality. Nitrogen play the vital role in the growth of fodder through the impact on cell elongation, cell division and inter-nodal expansion, it also play a major role in early establishment of the crop. Nitrogen is useful for the improvement of the leaf area by synthesis of enzymes and chlorophyll and also improves the leaf weight. Nitrogen improves the fodder yield through enhancement of growth parameters like plant height, number of tillers, leaf area index, number of leaves, leaf: stem ratio and dry matter accumulation. It is an essential part of protein and is a constituent of physiologically important compounds like nucleotides, vitamins, enzymes and hormones that promotes growth and development in crop plants (Kumar et al., 2001) and also improve the meristematic activity, it is useful for absorbing of nutrients from the soil efficiently and enhance the protein content of the crop through improvement in synthesis of carbohydrates. Forage oat especially multi-cut oat cultivars are heavy feeder of nutrients and remove large amount of nutrients from the soil. Nitrogen availability to the plant directly influence the forage yield, it is the reason to provide the nitrogen with the split applications. Split application of nitrogen improves the availability of the nutrient to the crop and improves the nitrogen use efficiency. 
In general farmers use the nitrogen $120 \mathrm{~kg} \mathrm{ha}^{-1}$ with improper doses in oat crop but nitrogen @ $160 \mathrm{~kg} \mathrm{ha}^{-1}$ with split applications gave the higher yields than farmer practices (Chouhan et al., 2014).

Cutting management is the one of the important factor to influence the fodder crop growth, yield and quality. In general cutting management may fallowed in fodder crops for higher yields. Cutting exhibits the effect on nutrient and natural resource utilization by the crop. As compared to single cut multi cut crops absorb more nutrients, which directly influence the nitrogen content, protein content and other quality parameters of the crop.

Cutting is one of the main factor to influence the green and dry forage yield (Patel et al., 2013), because it plays major role in biomass synthesis. In oat crop commonly gave two cuttings are at different stages, but $1^{\text {st }}$ cut at 60 DAS and $2^{\text {nd }}$ cut at $50 \%$ flowering gave the better growth and yield (Sharma et al., 2001).

\section{Materials and Methods}

The field experiment was conducted at Crop Research Centre of Sardar Vallabhbhai Patel University of Agriculture and Technology, Meerut (U.P.) during rabi season 2015-16. The climate of this region is sub-tropical and semi-arid and climate characterized with summers and extremely cold winters. The mean maximum temperature of this region is about $43^{\circ} \mathrm{C}$ to $45^{\circ} \mathrm{C}$ is not uncommon during summer while very low temperature $\left(1-2^{0} \mathrm{C}\right)$ accompanied by frost may be experienced in December-January. The winters are cool; frost generally occurs towards the end of December and may continue till the end of January. The monsoon generally begins during the third week of June and desists by the end of September. The total precipitation and its distribution in this region various largely about 75 to $85 \%$ of it's received during July to September and few showers are also a common feature during the month of December to January and in late spring season. Mean weekly meteorological data for the season during experimentation period (2015-2016) based on observations collected at meteorological observatory of SVPUA\&T, Modipuram, Meerut. Total precipitation of $211.30 \mathrm{~mm}$ was received during the experimentation period. The maximum temperature being $32.71^{\circ} \mathrm{C}$ was recorded in $13^{\text {th }}$ standard week. While, the minimum temperature was $8.57^{\circ} \mathrm{C}$ in $51^{\text {th }}$ standard week and the Relative Humidity ranged from 45.4 to $66.2 \%$ recorded, respectively in the morning. Ten treatment combinations comprising of five levels of nitrogen viz., 0 $\mathrm{kg} \mathrm{ha}^{-1} \mathrm{~N}(\mathrm{~N} 0), 40 \mathrm{~kg} \mathrm{ha}^{-1} \mathrm{~N}(\mathrm{~N} 1), 80 \mathrm{~kg} \mathrm{ha}^{-1}$ $\mathrm{N}(\mathrm{N} 2), 120 \mathrm{~kg} \mathrm{ha}^{-1} \mathrm{~N}(\mathrm{~N} 3)$ and $160 \mathrm{~kg} \mathrm{ha}^{-1}$ and two cuttings, single cut at 50\% flowering stage and first cut at 60 DAS and second cut at $50 \%$ flowering. Oat seed were drilled by adopting a spacing of $25 \mathrm{~cm}$. Kent cultivar was used in the study.

In plant total nitrogen was determined by kjeldhals method. In a digestion tube $0.5 \mathrm{gm}$ finally powdered plant samples was taken and added $10 \mathrm{ml}$ of concentrated $\mathrm{H}_{2} \mathrm{SO}_{4}+1 \mathrm{gm}$ digestion mixture $\left(\mathrm{K}_{2} \mathrm{SO}_{4}+\mathrm{CuSO}_{4} .5 \mathrm{H}_{2} \mathrm{O}\right)$, and kept for overnight, than heating was done in digestion chamber till the clear colourless solution appears. Cooled digest was shifted to distillation unit.

The content was distilled for 10 minutes using $40 \% \mathrm{NaOH}$ and distillate was collected in a conical flask containing $4 \%$ Boric acid mixture. The distillate was finally titrated against standardized $\mathrm{H}_{2} \mathrm{SO}_{4}$, once the colour change from bluish green to permanent pale pink colour note the burette reading.

At each harvest nitrogen content (\%) was multiplied with factor 5.73to convert into protein content (\%). The protein yield was calculated as per formula given below: 
Dry matter yield $\left(\mathrm{kg} \mathrm{ha}^{-1}\right) \mathrm{x}$ Protein content $(\%)$

Protein yield $\left(\mathrm{kg} \mathrm{ha}^{-1}\right)=$

100

\section{Results and Discussion}

\section{Nitrogen content in straw (\%)}

Nitrogen content in straw was affected significantly by nitrogen levels but not by the cutting-management. The related data are represented in table 1 .

Nitrogen content in the plant was affected significantly by nitrogen levels, nitrogen content of plant decline with the advancement in crop growth. Application of $160 \mathrm{~kg} \mathrm{~N} \mathrm{ha}^{-1}$ resulted in significantly higher nitrogen content than lower levels. Nitrogen content of the plant increased significantly with the successive increment in nitrogen levels. Cutting management exhibited nonsignificant effect on nitrogen content in plant.

The higher nitrogen content in plants might be due to better root development. The decrease in nitrogen content with age might be due to decrease in nitrogen uptake and dilution with increased structural carbohydrates content of aging crops. Nitrogen content was higher in double cut than single cut system. Similar result was also reported by verma (I984).

\section{Protein content $(\%)$}

Nitrogen levels and cutting management affected the protein content significantly. Interaction effect between nitrogen content and cutting management was found nonsignificant. The data are represented in table 2.

Protein content was affected significantly by nitrogen levels. Among the all nitrogen levels, $160 \mathrm{~kg} \mathrm{ha}^{-1}$ gave the maximum protein content at second cut $(11.02 \%)$ which was significantly higher than rest of doses. Moreover, in all other treatments protein content increased significantly with successive increase of nitrogen levels.

Cutting management also exhibited significant effect on protein content. Among the different cutting practices, double cut was gave more protein content than single cut at second cutting.

Table.1 Effect of nitrogen levels and cutting management on nitrogen content (\%) in plant

\begin{tabular}{|c|c|c|}
\hline \multicolumn{3}{|c|}{ Nitrogen content $(\%)$} \\
\hline & $1^{\text {st }}$ cut & $2^{\text {nd }}$ cut \\
\hline \multicolumn{3}{|l|}{ Nitrogen levels $\left(\mathrm{kg} \mathrm{ha}^{-1}\right)$} \\
\hline $\mathrm{N}-0$ & 1.52 & 1.12 \\
\hline $\mathrm{N}-40$ & 1.65 & 1.43 \\
\hline $\mathrm{N}-80$ & 1.79 & 1.53 \\
\hline $\mathrm{N}-120$ & 2.10 & 1.73 \\
\hline$N-160$ & 2.50 & 1.92 \\
\hline $\operatorname{S.Em}( \pm)$ & 0.010 & 0.001 \\
\hline CD at $5 \%$ & 0.030 & 0.020 \\
\hline \multicolumn{3}{|l|}{ Cutting management } \\
\hline At $50 \%$ flowering & - & 1.54 \\
\hline At 60 DAS and $50 \%$ flowering & 1.91 & 1.55 \\
\hline S.Em ( $( \pm)$ & - & 0.005 \\
\hline CD at $5 \%$ & - & NS \\
\hline
\end{tabular}


Table. 2 Effect of nitrogen levels and cutting management on protein content (\%) of forage oat

\begin{tabular}{|c|c|c|}
\hline \multicolumn{3}{|c|}{ Protein content $(\%)$} \\
\hline & $1^{\text {st }}$ cut & $2^{\text {nd }}$ cut \\
\hline \multicolumn{3}{|l|}{ Nitrogen levels $\left(\mathrm{kg} \mathrm{ha}^{-1}\right)$} \\
\hline $\mathrm{N}-0$ & 8.70 & 6.45 \\
\hline $\mathrm{N}-40$ & 9.45 & 8.25 \\
\hline $\mathrm{N}-80$ & 10.25 & 8.77 \\
\hline$N-120$ & 12.05 & 9.83 \\
\hline $\mathrm{N}-160$ & 14.35 & 11.02 \\
\hline $\operatorname{S.Em}( \pm)$ & $\mathbf{0 . 0 8}$ & $\mathbf{0 . 0 3}$ \\
\hline CD at $5 \%$ & 0.25 & 0.11 \\
\hline \multicolumn{3}{|l|}{ Cutting management } \\
\hline At $50 \%$ flowering & & 8.78 \\
\hline At 60 DAS and $50 \%$ flowering & 10.96 & 8.95 \\
\hline S.Em $( \pm)$ & $\ldots$ & $\mathbf{0 . 0 2}$ \\
\hline CD at $5 \%$ & & $\mathbf{0 . 0 7}$ \\
\hline
\end{tabular}

Table.3 Effect of nitrogen levels and cutting management on protein yield $\left(\mathrm{kg} \mathrm{ha}^{-1}\right)$

\begin{tabular}{|c|c|c|}
\hline \multicolumn{3}{|l|}{ Protein yield $\left(\mathrm{kg} \mathrm{ha}^{-1}\right)$} \\
\hline & $1^{\text {st }}$ cut & $2^{\text {nd }}$ cut \\
\hline \multicolumn{3}{|l|}{ Nitrogen levels $\left(\mathrm{kg} \mathrm{ha}^{-1}\right)$} \\
\hline $\mathrm{N}-0$ & 67.6 & 589.5 \\
\hline $\mathrm{N}-40$ & 117.8 & 822.6 \\
\hline $\mathrm{N}-80$ & 137.5 & 948.2 \\
\hline $\mathrm{N}-120$ & 187.9 & 1153.0 \\
\hline $\mathrm{N}-160$ & 255.3 & 1385.0 \\
\hline $\operatorname{S.Em}( \pm)$ & 2.25 & 7.05 \\
\hline CD at $5 \%$ & 6.55 & 20.46 \\
\hline \multicolumn{3}{|l|}{ Cutting management } \\
\hline At $50 \%$ flowering & & 1195.0 \\
\hline At 60 DAS and $50 \%$ flowering & 153.22 & 764.0 \\
\hline S.Em ( $( \pm)$ & & 4.45 \\
\hline CD at $5 \%$ & & 12.94 \\
\hline
\end{tabular}

\section{Protein yield $\left(\mathrm{kg} \mathrm{ha}^{-1}\right)$}

Nitrogen levels and cutting management exhibited a significant effect on protein yield. The related data are represented in table 3.

Among the all nitrogen levels, $160 \mathrm{~kg} \mathrm{ha}^{-1}$ $\left(1385 \mathrm{~kg} \mathrm{ha}^{-1}\right)$ gave the maximum protein yield at $2^{\text {nd }}$ cutting, it was significantly higher than protein yield recorded with other nitrogen levels and higher than control plot
(589.5 kg ha $\left.{ }^{-1}\right)$. Protein yield significantly increased with successive increment in nitrogen levels. Cutting management also exhibited significant effect on protein yield. Among the different cutting practices, single cut gave more protein yield (1195 kg ha-1) which was higher than double cutting practises $\left(764 \mathrm{~kg} \mathrm{ha}^{-1}\right)$.

The significantly higher protein yield in single cut system compared to two cut 
systems might be due to high dry matter yield in single cut system. Kumar et al., (2001) reported that two cut systems gave significantly more crude protein content because of weighted average value for two cut systems being higher due to much higher crude protein of the first cut. The results are in conformity with the findings of Pisal et al., (1993) and Singh (2004).

In the present investigation nitrogen content, protein content and protein yield increased with nitrogen level. These characters are increased significantly upto $160 \mathrm{~kg} \mathrm{~N} \mathrm{~kg} \mathrm{ha}{ }^{-1}$ at all the growth stages. The data indicated that nitrogen content was decreased with delay in first cutting. Cutting shows nonsignificant effect on nitrogen content in the plant. But comparatively double cutting management showed better nitrogen content than single cut.

The data presented revealed that double cut at 60 DAS and 50\% flowering gave significantly higher crude protein content than single cutting managements. Crop harvested once at $50 \%$ flowering produced significantly higher crude protein yield than double cutting managements.

\section{References}

Anonymous (2009). Available in: <http:// www.fao.org/ statistical database> [accessed 245 2016].

Chouhan, M., Gudadhe, N.N., Dinesh Kumar, A. K., Kumawat and Kumar, R. (2014). Transplanting dates and nitrogen levels influences on growth, yield attributes, and yield of summer pearlmillet. The Biasean 10 (3): 1295- 1298.

IGFRI (2011). Vision 2030: In: Pandey, K C., Roy, AK. (ed) Forage Crops Varieties. IGFRI, Jhanshi, India 23-27.

Jat. R.K., Patel, A.G., Shviran, A., Bijarnia, A.L. and Bhunwal, V. (2014). Response of oat (Avena sativa L.) on quality and economics to nitrogen and phosphorus levels under North Gujarat agroclimatic conditions. Journal of Crop and Weed 10(2):492-494

Kumar, A., Jaiswal, R. S., Verma, M. L., and Joshi, Y. P. 2001. Effect of nitrogen level and cutting management on yield and quality of different varieties of oat fodder. Indian Journal of Animal Nutrition 18 (3): 262-266.

Kumar, A., Jaiswal, R.S., Verma, M.L., and Joshi, Y.P. (2001). Effect of nitrogen level and cutting management on yield and quality of different varieties of oat fodder.Indian Journal of Animal Nutrition18 (3):262-266.

Kumar, S., Agrawal, R. K., Dixit, A. K., Rai, A. K., Singh J. B. and Rai, S.K. (2012). Forage Production Technology for Arable Lands. Technology Bulletin 39 (9): 255-260

Neelar, A. (2011). Response of oat genotypes to seed rate and nitrogen levels on forage yield and quality under irrigation. M.Sc. (Ag) thesis submitted to Department of Agronomy, University of Agricultural Sciences, Dharwad, India.

Patel, T.U., Arvadia, M.K., Patel, D.D., Thanki, J.D. and Patel, H.M. (2013).Response of oat (Avena sativa L.) to cutting management and times of nitrogen application. Crop Reaserch and Research on Crops 14(3): 902-906.

Pisal, A. A., Pntil, S. K. and Desale, J. S. 1993. Response of oat to cutting management and nitrogen levels for forage. Journal of Maharashtra Agricultural University 18 (1): 73-76.

Sharma. S.K, Bhunia, S.R. and Yadav, D.K. (2001).Response of oat (Avena sativa L.] to cutting management, method of sowing and nitrogen. Forage Research 27 (3): 167-170.

Singh, H. 2004. Effect of cutting management 
on forage yield and quality of oat (Avena sataiva L.) varieties. Thesis, M.Sc. G. B. Pant University of Agriculture and technology, pantnagar. Tiwana, U.S., Puri, K.P. and Chaudhary, D.P. (2008). Fodder productivity quality of multicut oat grown pure and in mixture with different seed rates of sarson.
Forage Research 33(4): 224-226.

Verma, S. S. 1984. Studies or growth, yield and quality of forage oats (Avena sativa L.) Under different levels of nitrogen and cutting managements. Thesis, $\mathrm{M}$. Sc. G. B. Pant University of Agriculture and Technology, Pantnagar.

\section{How to cite this article:}

Bollaveni Sathish Kumar, Raj Vir Singh, Akhilesh Kumar Gupta and Ravinder, J. 2017. Effect of Nitrogen Levels and Cutting Management on Nitrogen Content, Protein Content and Protein Yield of Fodder Oat (Avena sativa L.). Int.J.Curr.Microbiol.App.Sci. 6(7): 2077-2083. doi: https://doi.org/10.20546/ijcmas.2017.607.245 